\title{
SEMIOTICS OF WAYANG GOLEK LINGKUNG SENI GIRIHARJA'S SHOW AS A LEARNING SOURCE OF CIVIC EDUCATION
}

\author{
Abdul Azis, Kokom Komalasari, Iim Siti Masyitoh \\ Department of Civic Education, Indonesia University of Education \\ Jl. Setiabudi No.229 Bandung, Indonesia \\ abdulazis.goodcitizen@gmail.com
}

\begin{abstract}
Currently Civic Education learning in schools is still teacher centered learning. Consequently, the output of the study only focused on strengthening the aspects of knowledge (civic knowledge) students only. This research aims to provide an alternative learning civic education with student-centered learning methods, through the semiotics of Wayang Golek Lingkung Seni Giriharja as a learning resource. The research method used ethnography with a qualitative approach. The results showed that semiotics Wayang Golek Lingkung Seni Giriharja can be maximized as a learning resource civic education in citizenship competencies development of student. They will be active to dig semiotic values contained on the Wayang Golek Lingkung Seni Giriharja by means of learning material to link that is being discussed.
\end{abstract}

Keywords: semiotics, wayang golek, civic education

Adult civic education learning is not yet able to strengthen citizenship competencies the students as a whole. This is because the civic education study developed too centered on the teacher, so that the output of the process of learning just focusing on strengthening the aspects of knowledge. Meanwhile in civic education, competence learning citizenship expected consists of three key components, namely the Civic Knowledge relating to the content or what is supposed to be known by the citizen; Civic skills i.e. intellectual and participatory skills relevant citizen; and Civic Disposition that hinted at the public or private character of which is essential for the maintenance and development of constitutional democracy (Branson in Budimansyah \& Suryadi, 2008. In response to this, then developed a learning-based civic education etnopedagogi with learning process based on students. The concept of etnopedagogi basically aimed to improve the situation (social and cultural reconstruction) through pedagogy (education) (Suratno, 2015). Learning methods such as these can encourage teachers to be a mediator and facilitator responsible for motivating, stimulating and broadening the understanding of students from a variety of sources and media used (Saripudin, et al., 2014). This indicates that the educator is a key role in determining the success of learning. So, a good educator is creative, educators are always looking for new strategies or approaches in learning (Komalasari, 2010).

The idea of etnopedagogi serves as a knowledge or local wisdom to be a source of innovation and skills that can be used for the welfare of society (Alwasilah, 2009). In the world of education, this may encourage the formation of an attempt against the character of students. For character education based etnopedagogik is modern education directed at construction of the character of students by trying to adopt two types of pattern a more conventional education rests on individual growth process students, either physical or growth their psychic (Masyitoh, 2014). In the midst of the complexity of the problems of the nation, if not critically addressed modernization can be anesthetized so that someone forgot on identity and where as a nation Indonesia. The impact will be felt i.e. increasingly erode sublime cultural values of local, regional and national (Basyari, 2014). Wayang Golek is one local Sundanese wisdom that has character value i.e. the substance of the main character, basajan and selapan (Sabunga, 2014). The third type is the value of the character in semiotik has essence or substance through symbolic value through (symbolizing) or play (drama) that reflect the lives of creatures (humans, ani- 
mals, and nature) with all the problematic in its (Sabunga, 2014). Therefore the Wayang Golek Lingkung Seni Giriharja where appropriate to be used as a source of learning citizenship education.

\section{METHOD}

The methods used in this research is a ethnography with a qualitative approach. The research was conducted in two locations namely Padepokan Lingkung Seni Giriharja and Baleendah Senior High School. Informant research consists of a dalang, Wayang Golek observer and teacher of civic education. The data collected through interview, observation and documentation is then analyzed using data reduction, data presentation, and data verification (Milles \& Haberman, 2007). The final data were validated using triangulation technique of data resources and collection technique.

\section{RESULTS AND DISCUSSION}

\section{Semiotics of Wayang Golek Lingkung Seni Giriharja's Show}

The concept of semiotics triadis relationship described as involving an object within the human mind (representamen) and interpretation (interpretan) (Peirce, 1998). In semiotics, the meaning of Peel Pierce looked at a sign not just the cognition structure reflected from what can be seen by man, more of a semiotics is a series of processes of semiosis, i.e. a process definition to a sign in a cognitive contrast of something that can be perceived in the sensorial or can think about. Semiotik values referred to in this research is the symbolic values contained in the Wayang Golek Lingkung Seni Giriharja. Is there any study values the semiotics in General performed against: 1) the form of Wayang Golek, which in this case forms a way can give a touch of good and bad character values on each Wayang Golek figures; 2) the linguistic aspect of meaning, i.e. phrases contained in some parts in performances of Wayang Golek as opening song by Sinden, Murwa (the song first performed by dalang), Nyandra (prologue mastermind between scenes to be displayed) and Antawacana, (monologue and dialogue characters of Wayang Golek); and 3 ) play in this story that has a moral value and substance that represent the social life of the community in the religious life, society, nation and State.

\section{Development of Competencies of Citizen- ship Students Through Integrating Semiotics Values Performances Of The Wayang Golek Into Civic Education Study}

The development of civic education based etnopedagogi learning is done by making the Wayang Golek Lingkung Seni Giriharja as a source of learning. In the aspect of the development of socio-cultural values, students can explored the use of wayang golek as learning resources by finding the values of life as cageur (healthy), bageur (good), bener (right), clever (clever), silih asah (teach each other), silih asih (love), silih asuh (caring for each other), discipline, mutual and deliberation (Saripudin, et al., 2014). The value is a representation of the philosophy of living communities in West Java which is mutually love each other, mutual teaching and caring for each other.

Based on the research results, the first step is done by teachers in integrating such values is drafting the implementation of learning (RPP) citizenship education. In general the steps that should be contained in it IE: 1) Teachers divide students into several groups the following material should be discussed by the group; 2) every group should devise a working discussion of the matter in writing as well as looking for a snippet of Wayang Golek which are considered related to material covered; 3) each group presents footage of Wayang Golek for approximately 30 minutes, then presents an analysis of the values contained in the footage (from the aspect of the character of the persons appearing, linguistic aspects and the substance of value in the play the story) with a link to the materials reviewed; 4) after that other groups deliver its analysis against the Wayang Golek footage presented by a group of students in front of the class and relation to the learning materials that are being discussed in turns with other groups; 5) After all groups expressed its analysis results, the representative of each group giving a conclusion the analysis of the value in the Wayang Golek presented by a group of publishers as well as conducting assessment of the appearance of a group of publishers; 6) after that, the teacher do the clarification of the discussions that have been conducted by students in groups as well as a reflection of the value that is contained in a Wayang 
Golek footage related to the learning material that is being taught, then proceed with the evaluation of students with the way instruct each student to write down things that are interesting from a Wayang Golek performance impressions.

The application of learning like this can develop competencies citizenship studens. First, the development of civic knowledge students can be obtained through an understanding of the learning material using the substance of value to play Wayang Golek that many describe the setting of political life, society, religion or nation and State. Second, the development of civic disposition students can be obtained through the process of reflection a message of moral values and substance Wayang Golek performances that represent everyday life. Third, the development of civic skills students can look at the time student in groups cooperating to perform the selection of video footage related to the assigned material. This will give stimulus a skilled students to indicate participation in the life of nation and State, providing skills problem solving social problems, the Coalition held the skills, cooperation, and manage conflict, life skills, and others.

Wayang Golek show in fact is a symbol of the religious-mystical, that emblem of human life from birth to death as reflected in the structure of the puppet. In fact, almost all aspects of Wayang Golek, like other forms of physical puppets and various equipment used is a function of the symbolism (Nurgiyantoro, 2011). As a show that showcases the symbolic meaning of Wayang Golek performance, in semiotik have essence as symbolic of human life that reflect all forms of life and problems (Sabunga, 2014). In other words, performances of the Wayang Golek is a performing art that contain moral messages or meanings that can be accepted by the hearts and minds of audience. This would then encourage the audience to reflect those values into real life that exists around them as well as hers. In the context of performing arts, wayang golek have a sharp philosophical aspects, which in this case is described that man in fact occupy positions which have been determined by the Almighty with a variety of capabilities provided in accordance with the position that he would hold (Sabunga, 2014). Based on the research results, at least have found values semiotics in three aspects in the Wayang Golek Lingkung Seni Giriharja. The aspects in question fine aspect i.e. the form of wayang golek, aspects of linguistic and aspects of the play's story.
The form of Wayang Golek can represent the nature of the good and bad that is inside a human being in General. The character of the evil that is usually embedded in a blind character has the shape of the eye a plelengan, mungkal berang nose and gusen mouth come rows of teeth and fangs. So instead, the characters are usually contained in a Knight always described the shape of the eye of liyepan (small), bangir nose and his mouth mingkem with a put a smile, symbolizes the character of the gentle, considerate and was not easily upset. This thought Pierce connected as a process called semiosis involving human thought to to interpret a token which represents a nature of something or someone in a capacity in accordance with the values that grow and grow in the community in the form of conventions or agreements (Peirce, 1998). In other opinions asserted that semiotics of Wayang Golek can look at appearance and shape. Wayang golek as one work of art not only aims at presenting the beauty of mere form, but behind the beauty of the look on the face and form of Wayang Golek supremely laden with symbolic values as life (Hadijah, 2012).

On the linguistic aspect, the position of semiotics was placed as a field of study (semiologi) that includes aspects of linguistics. The basic assumption of this thinking is the deeds and actions of human beings which contains meaning or sign then there is a system or convention into the background. System or convention in question are linguistic or linguistic system, because the language is regarded as the dominant factor in any human performance due to an interaction with another human being in it (Saussure in Rusdy, 2015). Is there any value on linguistic semiotics contained in the Wayang Golek Lingkung Seni Giriharja can be seen in the opening song, Nyandra, Antawacana and Murwa. On the opening performances of Wayang Golek found values that are embedded through semiotics language expression or song lyrics. There are at least three moral messages that can be received by the audience in the opening performances of the Wayang Golek, namely: a) praise to God Almighty; b) reminds people to always be aware over the enjoyment of God are thankful; and c) pay homage to karuhun (the ancestors) by way of praying for them in order to get happiness in a natural grave and good in the hereafter would later go to heaven. The moral message is constructed by the relationship 
of the five basic concepts of semiotics i.e. 1) signnifier (bookmark) and the signified (alert); 2) form (the form) and content (content); 3) langue (language) and parole (speech); synchronic and diachronic) 4; syntagmatic and 5) and associative (Saussure, in Rusdy, 2015).

Next, murwa mastermind gives assertion that less and the Wayang Golek performance that is about right and wrong as well as fair and wrath reflected in people's lives today. Various ethical teaching moral values in sulukan (murwa) puppet implied in the material concerned, puppet sulukan which includes example, teaching good leadership, ethics and ethical teachings of wisdom and perfection of life with embodies the values that are expressed in the concept of "Sastrajendra Hayuningrat Pangruwating Diyu" meaning of the word King hosts who made all the ugly into well, evil becomes conscious and repentant (Kasidi, 2009). The concept of spirituality that are positioned in murwa aims to be able to show the presence of experience and awareness of the surrounding environment, in this case the audience (Nalan, 2012; Sabunga, 2014). Thus through murwa mastermind, the audience can take the religious values that symbolically communicated through language expression. Similarly, through the nyandra, at least the mastermind can give moral messages to the audience to be able to have a sense of love for the homeland, given the richness of the abundant natural resources that must be preserved and utilized with the just and wise. This indicates that a major problem in the puppet that is describing the process of human life in totality, as private, social beings, nor as a creature of God. Wayang golek typify human life in the world that has its own characteristics and distinctiveness because it has its own uniqueness and style said that is a genuine masterpiece of Indonesia which in this case is packed with the use of local languages (sundanese language) (Hardjowirogo, 1978).

Meanwhile, in antawacana contained moral values such as: human moral humanity to its creator; the human moral to himself; moral human being to other human beings; moral human beings to nature; the moral man against happiness and inner (Gumilar, 2015, pp. 69-70). On these antawacana, dalang do a monologue or dialogue between characters Wayang Golek containing moral message to be excavated by the audience. Is there any moral messages that can be received by the audience through the antawacana not always obtained on the characteristic figure is fine, but on the character of the evil character anyway. This means that in the audience as well as perform analysis semiotics reflection against the antawacana to then select and sort out the things that are good and bad. Thus the audience can reflect those values into life.

Based on the above description, the semiotics of Wayang Golek performance can serve as learning resources citizenship education. This is because the values contained in the Wayang Golek performance can become the reference material to stimulate learners to be able to participate in quality and responsible in the political life and society, both at national and local levels. The level of participation and the responsibilities of citizenship in the form of competence is affected by: a) mastery against the specific knowledge and understanding; b) the development of intellectual abilities and participatory; c) character development or specific mental attitude; and d) the correct commitment towards the fundamental values and principles of constitutional democracy (Komalasari, 2011 in Branson, p. 49). In addition to citizenship education is one of the fundamental instruments in the frame of national education, as a medium for the formation of the character of the nation (nation and character building) in the middle of heterogeneity and pluralism which became the main characteristic of the nation Indonesia (Suparlan, 2005). Addressing learning problems of civic education which is currently still centered on the teacher, then the use of a Wayang Golek performance as learning resources citizenship education is more emphasis on student centered learning. It is based on the principle of learning it self which in fact is an effort to develop a learning activity and creativity of students, through various interactions and learning experience (Mulyasa, 2002, p. 105). In this interactive atmosphere between students and teachers in the operationalization of learning components such as content, media, methods, resources and evaluation of learning.

Learning methods with centered to students as described in the above scheme can encourage learners to be active in civic education learning. In the process, the learning integrating values that live and thrive in the community as teaching materials and implemented within the basic concepts of citizenship through contextual learning model 
of Indonesia (Komalasari and Sapriya, 2016). The development of learning this kind of civic education is a social movement cultures of nationalities sinergistik done in an attempt to build a civic virtue and civic culture through active participation in religious, democratic and intelligent in its environment (Winataputra, 1999). In addition the development of civic education of this kind of learning is used to strengthen the civic education mission, namely citizenship education as the subjects carrying out the educational mission of anti-corruption (Komalasari and Saripudin, 2015). In the era of reform such as civic education is currently faced with the process towards a new Indonesia with the conception of civil society as an ideal order sosial-cultural through: (1) the socio-pedagogical; (2) socio-cultural; and (3) substantiveacademic (Suraya, 2009). The social dimension of cutural can develop citizens who participated in the activities of the Government as well as specifically delegated substantive dimension includes academic concepts, principles, and generalizations that all must support on quality citizenship education as a body of knowledge, so that between the school and the community should not be any gap of truth (Dewey, in Budimansyah, 2008). Thus the development of civic education based etnopedagogi learning it can develop competence in students citizenship dimensions of Civic Knowledge; Civic skills; and Civic Disposition (Branson, 1998).

First, the knowledge components (civic knowledge) covers the political, legal, and moral. In more detail the citizenship knowledge includes knowledge about principles and democratic processes, government agencies and non-government, national identity, based on the rule of law and the judiciary is free and impartial, constitution, national history, rights and responsibility of citizenship, human rights, civil rights and political rights (Ministry of National Education, 2003). Integrating values semiotics of Wayang Golek performances into Citizenship Education Learning can reinforce an understanding of learners towards learning material through some plays shown on the Wayang Golek that a lot of political life as well as a nation and a country. In addition, the use of textbooks that Indonesia's history of multiculturalism based conceptually integrates the principles of multiculturalism and the principle of values in scientific learning can support the learning of Civics-based etnopedagogic (Saripudin and
Komalasari, 2016). This is similar to the implementation of contextual learning that develops the integration of material presentation with words of wisdom from local, national, regional, and international students can inspire a contained in the civic education textbook (Komalasari and Saripudin, 2017). Wise words adapted to the context of the material covered in the book. Second, the component skills (civic skill) that need to be owned by private citizens, among other intellectual skills, social skills, the skill of the participatory (Winataputra, 2002). This can be seen at the time of the students in group shows video footage of election do cooperation with regard to material that is assigned. In this case it will be seen the participation of students actively by making use of the knowledge that he had to choose the social phenomena that correspond to the learning material in a Wayang Golek performance. Third, the components of attitude (civic disposition) citizenship refers to personal character traits and character development that are necessary for the maintenance and repair of a constitutional democracy. These components include personal character traits such as moral of responsibilities, self discipline, and respect for the value and dignity of humanity. Civic character traits such as civic spirit among others, courtesy, respect for the rule of law, critical thinking, the desire to listen, negotiate, and compromise is indispensable to the success of democracy (Winataputra, 2002). In this case the students would easily accept moral and reflection as well as the substance of the value delivered through performances of the Wayang Golek.

\section{CONCLUSION}

The semiotics of Wayang Golek Lingkung Seni Giriharja typify (symbolizing) or play (drama) which has the substance the value of character as a reflection of life beings with all problematics in it. The use of semiotics Wayang Golek as a source of learning Civics-based etnopedagogi is a development-centred learning to students (student centered learning). This learning method is expected to develop the competence of students through the citizenship activity and creativity of learners in a variety of interaction and learning experiences are developed with semiotics value in performances of Wayang Golek Lingkung Seni Giriharja. 


\section{REFERENCES}

Alwasilah, A.C., et al. 2009. Etnopedagogi: the cornerstone of the practice of education and teacher education. Bandung: Kiblat Buku Utama

Basyari, WI. 2014. Local wisdom values (Local Wisdom) traditions of Cirebon on society Memitu (study of the villagers Setupatok Subdistrict Mundu). Edunomic: Journal Volume 2 No. 12014

Branson, MS. 1999. Learn "Civic Education" of America (translation by Syarifudin, et al.). Yogyakarta: LKIS.

Budimansyah, D. and Suryadi, K. 2008. PKn and multicultural. Bandung: Civic Education Courses Indonesia University Of Education.

Budimansyah, D. 2008. "Revitalizing civic education Learning through practice of studying Citizenship (Project Citizen). In Acta Civicus Volume I, number 2 April 2008 Edition, Civic Education Program Graduate School. Bandung: UPI

Ministry Of National Education. 2003. The legislation of the Republic of Indonesia No. 20 of 2003 On the national education system. Jakarta: Department Of National Education.

Gumilar, G.C. 2015. Discourse of Wayang Golek Cepot Kembar from Giriharja 3 (Structural Studies and Etnopedagogik. Journal: Lokabasa vol. 6, no. 1, April 2015.

Hadijah, I. 2012. Comparative study of Wayang Golek Purwa Typical brass and West Java in the analysis of Sumedang Semiotik in 2007 through 2010. Chatarsis: Journal of Arts Chatarsis 1 (1) (2012), Educationhttp://journal.unnes.ac.id/ sju/index.php/chatarsis.

Hardjowirogo. 1978. The history of Wayang Purwa. Jakarta: Balai Pustaka,

Kasidi. 2009. The aesthetic Suluk Wayang Kulit Purwa Yogyakarta style Relevant For Ethics and morality. A dissertation on the Graduate Program Faculty Filasafat Gadjah Mada University. Yogyakarta: unpublished.

Komalasari, K dan Sapriya. 2016. Living Values Education in Teaching Materials to Develop Students' Civic Disposition. Journal: The new Educational Review, DOI: 10.15804/tner.2016.44.2.09
Komalasari, K. dan Saripudin, D. 2015. Integration of Anti-Corruption Education in School's Activitie. American Journal of Applied Sciences 2015, 12 (6): 445.451 DOI: 10.3844/ajassp.2015.445.451

Komalasari, K. dan Saripudin, D. 2017. A Model of Living Values Education-based Civic Education Textbooks in Indonesia. Journal: The new Educational Review, 2017 Vol. 47. No. 1 hal. 139 ISSN 1732-6729.

Komalasari, K. 2010. Contextual Learning Innovation diffusion in citizenship education. Journal of science education, vol. 17, no. 3, October 2010, pp. 218-224.

Komalasari, K. 2011. Contextual Learning contributions to the development of Citizenship Competencies the students of Junior High School in West Java. Journal MIMBAR, vol. XXVII, no. 1 (June 2011): 47-55.

Mulyasa, E. 2002. Kurikulum Berbasasis Kompetensi (Konsep, Kerakteristik, Implementasi). Bandung: Remaja Rosdakarya.

Masyitoh. 2014. Development of character education Based Etnopedagogik (Model Habituation in Two Neighborhood high school (HIGH SCHOOL) in West Java). Dissertation: Graduate School, UPI.

Miles, MB. and a. Huberman. 2007. The qualitative Data analysis, source Book about new methods. Jakarta: Indonesia's University Press.

Nalan, SA. 2012. Communication Concept in Dalang Asep Sunandar Sunarya Wiwaha Mandala. Art Journal Cultural Stage \& vol. 22, no. 3, July-September 2012:225 - 350

Nurgiyantoro, B. 2011. Wayang and Character Development of The Nation. Journal Of Character Education. 1 (1), 18-34.

Rusdy, ST. 2015. Semiotics \& Philosophy; Puppet: puppet entry for critical analysis. Jakarta: Yayasan Kertagama.

Pierce, C.S. 1998. Principles of Philosophy, Volume 1, Edited by: Charles Hartshorne and Paul Weiss. England: Colected Papaers of Charles Sanders Peirce, Thoemmes Press. 
Pierce, C.S. 1998. Element of Logic, Volume 2, Edited by: Charles Hartshorne and Paul Weiss. England: Colected Papaers of Charles Sanders Peirce, Thoemmes Press. Sabunga, B., et al. 2014. Wayang Golek education values: Their potential to strengthen nationalism. International Journal of Education and Management Studies, Page 287292, Volume - 4 (2014), Issue - 4.

Saripudin, D. and Komalasari, K. 2016. The Development of Multiculturalism Values in Indonesian History Textbook. American Journal of Applied Sciences 2016, 13 (6): 827.835 DOI: $10.3844 /$ ajassp.2016.827.835.

Saripudin, D., et al. 2014. The Development of Students' Sociocultural Values through Wayang Golek as a Learning Source in Social Studies. Jurnal: Research on $\mathrm{Hu}$ manities and Social Sciences. ISSN (Paper)2224-5766 ISSN (Online)2225-0484 (Online) Vol.4, No.6, 2014.

Suparlan, P. 2003. Bhineka Tunggal Ika: Diversity, languages or cultures. Journal of
Anthropology in Indonesia, Th. XXVII, no. 72. Jakarta: UI [University of Indonesia] and Yayasan Obor Indonesia

Suratno, T. 2015. Interpret Etnopedagogi as the Foundation of Education Teacher Education at the University of Indonesia. Proceedings UPI: 1st International Conference on Sociology Education (ICSE UPI 2015), The authors-Published by Atlantis Press.

Suraya, A. 2009. The role of Portfolio-based Pkn Learning in developing the competencies of Citizenship: a descriptive Study on students of Class XI IPS 3 High School Laboratory Pilot UPI. Indonesia University Of Education: Thesis.

Winataputra, US. 1999. The concept and strategy of Pancasila Moral education in high school. Jakarta: P2LPTK Higher Education.

Winataputra, US. 2002. Teaching And Learning Strategies. Jakarta: Center For The Publication Of The Open University. 